Rangkiang: Lurnal Pengabdian Pada Masyarakat

UP3M STKIP PGR/ Sumatera Barat

ISSN: (2721-2688) Vol. 2 No. 2 (Desember 2020): 60-65

\title{
THE DEVELOPMENT OF TEACHERS COMPETENCE ON CLASS ACTION RESEARCH AND SCIENTIFIC PUBLICATION
}

\section{PENGEMBANGAN KOMPETENSI GURU DALAM PENELITIAN TINDAKAN KELAS DAN PUBLIKASI ILMIAH}

\author{
Nurul Frijuniarsi ${ }^{1}$, Natalia Tri Astuti ${ }^{2}$ \\ ${ }^{1,2}$ Fakultas Teknik dan IImu Komputer Universitas Indraprasta PGRI \\ *E-mail: frijuniarsinurul@gmail.com, natnatalia.lia@gmail.com
}

\begin{abstract}
The aim of this community service program is to develop teachers' skill in Class Action Research and scientific publication, regards to the needs of the participants as teachers. The participants are the teachers of Wijaya Kusuma Kindergarten, Lenteng Agung East Jakarta. In collecting data the writers conduct some methods; survey, observation and interview. Meanwhile the direct method is adopted as well as grup discussion on the implementation, followed by project-based method in which participants are required to write the proposal, perform the research, and make a report. This program takes four months starting from March to June, and the result shows that the participants get satisfying knowledge and skill, not only in conducting class action research, but also write the proposal and report, and convert it into a scientific article worth to publish.
\end{abstract}

Keywords: teachers competence, class action research, scientific publication.

\begin{abstract}
ABSTRAK
Tim pelaksana mengadakan kegiatan pengabdian masyarakat berupa sosialisasi dan pendampingan kegiatan Penelitian Tindakan Kelas (PTK) sesuai dengan kebutuhan guru-guru di TK Wijaya Kusuma yang terletak di Lenteng Agung Jakarta Timur, guna mengembangkan kompetensi mereka sebagai seorang guru. Metode survey, observasi dan wawancara digunakan dalam tahap pengumpulan data untuk mengidentifikasi permasalahan mitra. Sedangkan metode yang digunakan dalam pelaksanaanya yaitu ceramah dan disikusi, dilanjutkan dengan praktik langsung penulisan proposal dan laporan akhir, serta penyusunan artikel ilmiah. Setelah dilakukan kegiatan pengabdian kepada masyarakat ini selama 4 bulan ini, peserta memiliki pengetahuan dan kemampuan dalam melaksakan Penelitian Tindakan Kleas (PTK). Peserta mampu menyusun proposal penelitian, melaksanakannya di kelas masing-masing, dan membuat laporan tertulis, serta mengubah laporan tersebut menjadi sebuah artikel ilmiah.
\end{abstract}

Kata kunci: Kompetensi guru, penelitian tindakan kelas, publikasi ilmiah. 


\section{Rangkiang: durna/ Pengabdian Pada Masyarakat UPSM STKIP PGR/ Sumatera Barat}

ISSN: (2721-2688) Vol. 2 No. 2 (Desember 2020): 60-65

\section{PENDAHULUAN}

Seorang guru dituntut untuk bisa memberikan pengajaran yang baik bagi para peserta didiknya. Seorang guru yang baik seyogyanya mampu menciptakan kondisi dan lingkungan belajar yang kondusif sehingga memudahkan peserta didik dalam menyerap ilmu dan informasi yang diberikan ,oleh karena itu, pemerintah memberikan apresiasi kepada para guru yang mampu menciptakan suasana belajar yang nyaman melalui metode-metode yang yang variatif dan efektif sebagai bentuk dukungan kepada guru untuk terus meningkatkan kemampuan mereka dalam melakukan tugas mengajar di kelas. Menurut Permenegpan \& RB Nomor 16 tahun 2009, tentang Jabatan Fungsional Guru dan Angka Kreditnya, guru wajib dinilai kinerjanya dan melaksanakan kegiatan Pengembangan Keprofesian Berkelanjutan (PKB). Salah satu kegiatan PKB yang dapat dilakukan oleh guru adalah melaksanakan penelitian. Untuk mewujudkan hal tersebut guru harus mempunyai kemampuan meneliti, khususnya Penelitian Tindakan (Legiman, 2015).

Penelitian Tindakan Kelas (PTK) merupakan penelitian yang dapat dirasakan langsung manfaatnya oleh guru, karena sebagai seorang pengajar, kelas merupakan laboratorium eksperimen guru, yang erat dengan kesehariannya atau dengan kata lain mereka dapat melakukan penelitian tanpa pergi ke tempat lain (Sukardi, 2011 dalam Nurizzati, 2014) Asumsi yang mendasari pelaksanaan penelitian tindakan adalah bahwa orang akan belajar dan mengembangkan pengetahuan dari pengalaman sendiri yang konkrit; melalui pengamatan dan refleksi dalam pengalaman tersebut; melalui pembentukan konsep abstrak dan generalisasi; serta dengan menguji implikasi konsep dalam situasi baru. Jadi, Penelitian Tindakan Kelas (PTK) sebenarnya bukanlah hal baru bagi dunia pendidikan terutama seorang guru. Seorang guru dituntut untuk melakukan penelitian, salah satunya adalah PTK. Selain untuk memperbaiki pembelajaran di kelas juga untuk mendapatkan nilai kum dalam penilaian kinerja guru profesional. (Nurizzati, 2014).

Pada era maju dan berkembang sekarang ini, hasil dari penelitian yang dilakukan dirasa kurang cukup jika hanya tersimpan sebagai arsip pribadi untuk guru saja. Publikasi hasil penelitian berupa artikel atau publikasi ilmiah dirasa sangat perlu untuk pengembangan hasil penelitian dimasa mendatang. Publikasi hasil penelitian ilmiah juga dapat digunakan sebagai acuan bagi penelitian lain atau pengembangan penelitian lainnya sehingga dapat lebih berkembang dan bermanfaat. Merujuk pada pernyataan Darmalaksansa dan Suryana (2018), publikasi ilmiah dapat dipandang sebagai sebuah indikator kinerja seorang dosen ataupun akademisi lainnya, dimana hasil penelitian yang telah dilakukannya belumlah memiliki makna yang berarti jika tidak dipublikasikan, baik pada media online ataupun cetak. Adapun yang dimaksud dengan publikasi ilmiah yaitu penerbitan hasil penelitian berupa artikel pada jurnal ilmiah nasional ataupun internasional yang berbasis open journal system (OJS). Publikasi ilmiah yang dilakukan guru pada dasarnya merupakan wujud dari profesionalisme guru, namun begitu tidak semua guru memiliki pengetahuan dan kemampuan dalam melaksanakan sebuah penelitian dan mempublikasikan hasil penelitiannya dalam sebuah jurnal ilmiah. Menyadari hal itu, maka tim dosen Universitas Indraprasta PGRI berinisiatif untuk memberikan pelatihan kepada guruguru di TK Wijaya Kusuma sebagai bentuk pelaksanaan salah satu poin dalam Tri Darma Perguruan Tinggi, pengabdian kepada masyarakat. 


\section{Rangkiang: durna/ Pengabdian Pada Masyarakat UPSM STKIP PGR/ Sumatera Barat}

ISSN: (2721-2688) Vol. 2 No. 2 (Desember 2020): 60-65

\section{METODE}

Kegiatan pengabdian masyarakat ini dilaksanakan selama empat bulan, terhitung dari bulan Maret sampai dengan Juni 2019. Metode survey, observasi, dan wawancara digunakan pada tahap awal untuk mendapatkan data terkait kondisi mitra serta kebutuhannya sehingga tim bisa merumuskan target serta solusi sesuai dengan permasalahan yang dihadapi oleh pihak mitra. Lalu diikuti dengan proses perijinan kepada pihak TK Wijaya Kusuma yang diwakili oleh ketua kelompok. kemudian langkah terakhir dalam tahap persiapan adalah pengadaan media pelatihan, dalam hal ini persiapan alat serta metode yang akan digunakan dalam pelatihan.

Sedangkan dalam pelaksanaannya, beberapa metode diadopsi sesuai dengan target pertemuan yg telah dirumusakan oleh tim pelaksana dan pihak TK Wijaya Kusuma. Pelaksanaan pelatihan dilaksanakan sebanyak lima kali pertemuan dengan durasi 2 jam untuk tiap pertemuan. Metode ceramah dan diskusi digunakan pada pertemuan pertama dan kedua, dimana peserta diberikan materi mengenai hakikat dari Penelitian Tindakan Kelas (PTK) beserta tata cara pelaksanaan dan hal-hal yang harus diperhatikan dalam pelaksanaan penelitian ini, di akhir sesi tim meminta peserta untuk menyusun sebuah proposal PTK secara berkelompok, dan tentunya dengan dampingan dari tim dosen pelaksana. Peserta diberikan waktu untuk melaksanakan penelitian tersebut secara mandiri dengan sasaran peserta didik yang mereka ajar di kelas masing-masing. Pada pertemuan selanjutnya peserta akan diberikan waktu untuk menyusun laporan akhir Penelitian Tindakan Kelas. Pada pertemuan ke empat tim pelaksana memberikan materi, masih dengan menggunakan metode ceramah, mengenai publikasi ilmiah. Pada pertemuan terakhir para peserta diminta untuk mengubah laporan PTK yang telah mereka buat kedalam format artikel pada salah satu jurnal ilmiah yang telah ditentukan oleh tim pelaksana.

Tahap akhir dalam kegiatan ini adalah evaluasi yang mencakup tidak hanya hasil akhirnya melainkan juga proses yang sudah dilakukan dan berlaku untuk semua tahap yaitu mulai dari tahap persiapan sampai dengan tahap pelaksanaan kegiatan. Tahap evaluasi ini dilanjutkan dengan kegiatan penyusunan laporan. Tahap ini bertujuan untuk meguraikan kendala-kendala yang ditemukan selama pelaksaaan program pengabdian masyarakat ini, menemukan kelemahan serta kelebihan dalam prosesnya, serta meberikan penilaian terhadap hasil akhir, apakah sudah sesuai target atau belum

\section{HASIL DAN PEMBAHASAN}

Proses pelaksanaan program iptek bagi masyarakat ini secara umum dapat dikatakan berjalan dengan lancar, dimulai dari tahap persiapan sampai dengan tahap pelaksanaan. Untuk hasil dan pembahasan yang lebih jelas, akan dipaparkan uraian berikut ini:

1. Pertemuan Hari ke-1

Pada pertemuan pertama, tim pelaksana memaparkan materi mengenai apa itu Penelitian Tindakan Kelas; Latar belakang pelaksanaan penelitian, apa saja yang bisa menjadi masalah penelitian, alternatif pemecahan masalah, prosedur dan metodologi penelitian, tahapan siklus dalam PTK, serta sarat diterimanya keabsahan sebuah PTK. Di akhir sesi peserta diperkenankan untuk bertanya dan berdikusi mengenai materi yang sudah dipaparkan. Banyak sekali pertanyaan yang mereka ajukan karena pada dasarnya guru-guru di TK Wijaya Kusuma belum pernah melakukan penelitian sebelumnya. 


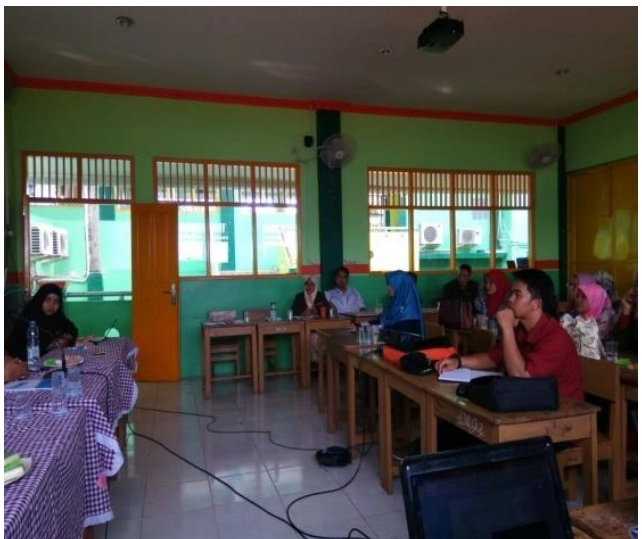

Gambar 1. Tim Pelaksana Memberikan Materi pada Pertemuan Pertama

2. Pertemuan Hari ke-2

Pertemuan kedua, peserta dibagi menjadi 3 kelompok. Kegiatan difokuskan kepada konsultasi peserta mengenai bagaimana cara menemukan masalah yang ingin mereka teliti. Peserta diminta memaparkan situasi kelas yang mereka ajar, target-target yang ingin dicapai, kesesuaian maupun ketidaksesuaian target dengan pencapaian, mengira-ngira apa penyebab ketidaksesuaian hasil capaian dengan target yang diharapkan, hal hal yang dirasa perlu untuk diperbaiki atau ditingkatkan, serta menyusun langkah-langkah dalam menemukan beberapa alternatif solusi. Hasil konsultasi dan diskusi tersebut lalu diaplikasikan kedalam penyusunan proposal penelitian. Lalu peserta diminta untuk melaksankan penelitian tindakan kelas tersebut di luar rangkaian pertemuan kegiatan abdimas ini.

3. Pertemuan Hari ke-3

Pada sesi ini peserta diminta untuk memaparkan hasil temuan penelitian mereka, lalu diarakan untuk menulis laporan dari hasil penelitian yang telah mereka lakukan. Tim pelaksana melakukan pendampingan dalam penyusunan laporan akhir penelitian. Pada proses ini tidak ditemukan kendala yang berarti, hanya masalah teknis seperti belum terbiasanya para peserta membuat sebuah laporan penelitian yang terstruktur.

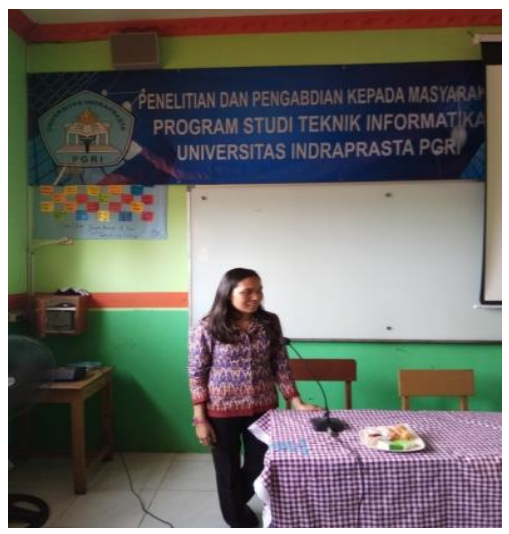

Gambar 2. Pemaparan Hasil Temuan oleh Peserta. 


\section{Pertemuan Hari ke-4}

Sesi ini ditujukan untuk memberikan pengetahuan serta wawasan peserta mengenai publikasi ilmiah. Tim pelaksana menjelaskan apa yang dimaksud publikasi ilmiah, jenis-jenis publikasi ilmiah, aturan-aturan dalam publikasi ilmiah, teknik pengutipan pada beberapa jurnal ilmiah, fomat penulisan atau template, plagiasi dalam publikasi ilmiah, dan hal-hal lainnya terkait publikasi ilmiah yang harus diketahui oleh peserta. Tim pelaksana juga memberikan kesempatan pada peserta untuk mengajukan pertanyaan serta mendiskusikannya.

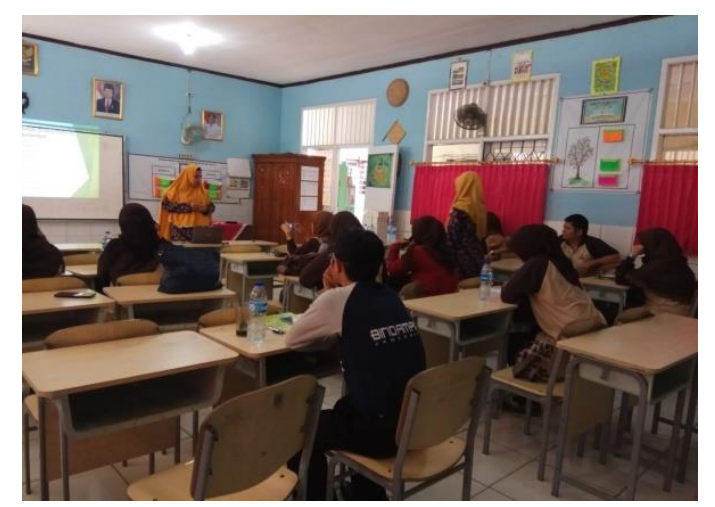

Gambar 3. Tim Dosen memberikan Materi Mengenai Publikasi Ilmiah.

5. Pertemuan Hari ke-5

Di pertemuan terakir ini, tim pelaksana mengarahkan atau mendampingi peserta dalam menulis sebuah artikel ilmiah dari laporan penelitian (PTK) yang telah mereka susun sebelumnya. Adapun artikel disusun dalam format (template) penulisan salah satu jurnal ilmiah yang diterbitkan oleh LPPM Universitas Indraprasta PGRI, yaitu Jurnal Ilmiah Kependidikan FAKTOR. Tim pelaksana juga memberikan contoh bagaimana caranya jika mereka ingin mengirimkan artikel tersebut melalui OJS (open journal system) LPPM Unindra dan beberapa OJS dari istitusi lain. Serta memperlihatkan contoh tahapan yang akan dialami selama proses pengajuan artikel sampai dengan artikel diterbitkan.

\section{SIMPULAN}

Setelah melakukan kegiatan pengabdian masyarakat berupa sosialisasi dan pelatihan mengenai Penelitian Tindakan Kelas, dapat disimpulkan bahwa peserrta dalam hal ini guru TK Wijaya Kusuma sebenarnya secara tidak langsung kerap melaksanakan prosedur teknis PTK di kelas masing-masing, yaitu mengidentifikasi permasalahan dalam pengajaran serta mencoba merumuskan solusi-solusi yang mungkin dapat meningkatkan hasil belajar siswa, namun begitu mereka tidak memiliki pengetahaun maupun kemampuan untuk menuangkang prosedur tersebut menjadi sebuah penelitian. Dengan diadakannya kegiatan ini, peserta mendapatkan pengetahuan mengenai PTK. Tidak hanya itu mereka mampu menyusun sebuah proposal penelitian beserta laporan akhirnya. Begitu juga dengan publikasi ilmiah. Setelah diberikan materi mengenai jenisjenis publikasi ilmiah serta contoh-contoh artikel ilmiah, peserta mampu menulis artikel ilmiah berdasarkan laporan penelitian yang telah mereka buat. 


\section{DAFTAR PUSTAKA}

Agustina, Entin T. 2013. Implementasi Model Pembelajaran Snowball Throwing untuk Meningkatkan Hasil Belajar Siswa dalam Membuat Produk Kria Kayu dengan Peralatan manual. Jurnal INVOTEC Vol. IX No. 1. FPTK UPI bekerjasama dengan APTEKINDO: Bandung.

Arikunto, Suhardjono, Supardi. 2008. Penelitian Tindakan Kelas. Jakarta: Bumi Aksara

Darmalaksana, W dan Yaya Sunarya. 2018. Korespondensi dalam Publikasi Ilmiah. Jurnal Perspektif Vol. 02, No. 01. UIN Sunan Gunung Jati Bandung.

Ditjen Dikti. 2013. Pandun Pelaksanaan Penelitian dan Pengabdian Kepada Masyarakat di Perguruan Tinggi. Jakarta: Ditjen Dikti Depdiknas.

Legiman. 2015. Penelitian Tindakan Kelas. Widyaiswara LPMP: Yogyakarta

Nurizzati, Yetti. 2014. Ketertolakan Hasil Penelitian Tindakan Kelas. Jurnal Edueksos Vol III No. 1: Jurusan Tadris IPS FITK IAIN Syekh Nurjati: Cirebon

Rahmawati, Diana. 2012. Penelitian Tindakan Kelas. Diakses pada tanggal 20 Maret 2019 melalui http:/www.academia.edu/download/35695504/penelitian-tindakan-kelas.pdf. 